\title{
Hemodialysis Technology
}




\section{Contributions to Nephrology}

\section{Vol. 137}

Series Editors

G.M. Berlyne Beersheva/Brooklyn, N.Y.

C. Ronco Vicenza 


\section{Hemodialysis Technology}

Volume Editors

Claudio Ronco Vicenza

Giuseppe La Greca Vicenza

113 figures, 28 in color, and 31 tables, 2002

KARGER $\quad \begin{aligned} & \text { Basel } \cdot \text { Freiburg } \cdot \text { Paris } \cdot \text { London } \cdot \text { New York } \cdot \\ & \text { New Delhi } \cdot \text { Bangkok } \cdot \text { Singapore } \cdot \text { Tokyo } \cdot \text { Sydney }\end{aligned}$ 


\section{Contributions to Nephrology}

Founded 1975 by Geoffrey M. Berlyne

\section{Claudio Ronco}

Department of Nephrology

St. Bortolo Hospital

I-36100 Vicenza (Italy)

\section{Giuseppe La Greca}

Department of Nephrology

St. Bortolo Hospital

I-36100 Vicenza (Italy)

Library of Congress Cataloging-in-Publication Data

Hemodialysis technology/volume editors, Claudio Ronco, Giuseppe La Greca.

p.; cm. - (Contributions to nephrology, ISSN 0302-5144; vol. 137)

Includes bibliographical references and index.

ISBN 3805574231 (hard cover : alk. paper)

1. Hemodialysis-Equipment and supplies. I. Ronco, C. (Claudio), 1951- II. La Greca, G.

III. Series.

[DNLM: 1. Renal Dialysis-instrumentation. 2. Renal Dialysis-methods. WJ 378 H48857 2002]

RC901.7.H45 H453 2002

$617.4^{\prime} 61059-\mathrm{dc} 21$

Drug Dosage. The authors and the publisher have exerted every effort to ensure that drug selection and dosage set forth in this text are in accord with current recommendations and practice at the time of publication. However, in view of ongoing research, changes in government regulations, and the constant flow of information relating to drug therapy and drug reactions, the reader is urged to check the package insert for each drug for any change in indications and dosage and for added warnings and precautions. This is particularly important when the recommended agent is a new and/or infrequently employed drug.

All rights reserved. No part of this publication may be translated into other languages, reproduced or utilized in any form or by any means electronic or mechanical, including photocopying, recording, microcopying, or by any information storage and retrieval system, without permission in writing from the publisher.

(C) Copyright 2002 by S. Karger AG, P.O. Box, CH-4009 Basel (Switzerland)

www.karger.com

Printed in Switzerland on acid-free paper by Reinhardt Druck, Basel

ISSN 0302-5144

ISBN 3-8055-7423-1 


\section{Contents}

XI Preface

Ronco, C.; La Greca, G. (Vicenza)

Opening Remark

1 The Role of Technology in Hemodialysis

Ronco, C.; La Greca, G. (Vicenza)

Vascular Access

13 Vascular Access Use and Outcomes: Results from the DOPPS Pisoni, R.L. (Ann Arbor, Mich.)

20 How to Achieve a High Rate (90\%) of Native Arteriovenous Fistulae Konner, K. (Cologne)

31 Diagnostic Methods for Vascular Access: Access Flow Measurements Leypoldt, J.K. (Salt Lake City, Utah)

38 Temporary Vascular Access for Hemodialysis Treatment. Current Guidelines and Future Directions Weijmer, M.C.; ter Wee P.M. (Amsterdam)

46 Prosthetic Devices for Vascular Access

Quarello, F.; Forneris, G.; Pozzato, M. (Turin)

54 Effect of Hemodynamic Conditions on Arteriovenous Fistula for Hemodialysis Access

Ene-Iordache, B.; Bruno, S.; Remuzzi, A. (Ranica); Remuzzi, G. (Ranica/Bergamo)

60 Quality Assurance and Continuous Quality Improvement in the Management of Vascular Access

Bosch, J.P.; Walters, B.A.J. (Fort Lauderdale, Fla.) 
Dialysis Membranes

70 Membranes for Dialysis. Composition, Structure and Function Clark, W.R. (McGaw Park, Ill./Indianapolis, Ind.); Gao, D. (Lexington, Ky.); Ronco, C. (Vicenza)

78 Methods of Sterilisation and Their Effects on Membrane Performance and Safety

Gavioli, G. (Mirandola); Gennari, M. (Munich) Bruns, S. (Glandorf)

85 Nano-Controlled Membrane Spinning Technology: Regulation of Pore Size, Distribution and Morphology of a New Polysulfone Dialysis Membrane

Bowry, S.K. (Bad Homburg)

95 Vitamin E-Modified Dialyzers

Galli, F. (Perugia)

106 Modified Cellulose Triacetate Membranes

Masuda, T. (Osaka)

111 The AN69ST Dialysis Membrane. A New Approach for Reducing Systemic Heparinization Renaux, J.-L.; Atti, M. (Lyon)

Hemodialyzers

120 Flow Distribution and Cross Filtration in Hollow Fiber Hemodialyzers

Ronco, C.; Brendolan, A.; Crepaldi, C.; Gastaldon, F. (Vicenza); Levin, N.W. (New York, N.Y.)

129 Optimal Use of Hemodialyzers

Leypoldt, J.K.; Cheung, A.K. (Salt Lake City, Utah)

138 Sterilization Procedures and Biocompatibility

Rodríguez-Benot, A.; Santamaría, R.; Martín-Malo, A.;

Aljama, P. (Córdoba)

146 Computerized Selection of Membranes and Hemodialyzers Ronco, C. (Vicenza); Ghezzi, P.M. (Cuneo)

Hoenich, N.A. (Newcastle/New York, N.Y.); Delfino, P. (Cuneo)

Adsorbents

158 Adsorbents: From Basic Structure to Clinical Application Ronco, C.; Bordoni, V. (Vicenza); Levin, N.W. (New York, N.Y.)

165 Biocompatibility of Sorbent Systems

Hoenich, N.A. (Newcastle upon Tyne) 


\section{Sorbent Augmented Dialysis Systems}

Winchester, F.J. (New York, N.Y.); Ronco, C. (Vicenza); Salsberg, J.; Yousha, E.; Brady, J.A. (New York, N.Y.); Cowgill, L.D. (Davis, Calif.); Choquette, M.; Albright, R.; Clemmer, J. (New York, N.Y.); Davankov, V.; Tsyurupa, M.; Pavlova, L.; Pavlov, M. (Moscow); Cohen, G.; Hörl, W. (Vienna); Gotch, F. (San Francisco, Calif.,); Levin, N.W. (New York, N.Y.)

\section{Use of Adsorbents in ARF Therapy}

Tetta, C. (Mirandola); Bellomo, R. (Melbourne); Formica, M.; Livigni, S.; Mariano, F. (Turin); Wratten, M.L. (Mirandola); Carraro, G. (Padua); Ronco, C. (Vicenza)

Dialytic Techniques

189 Low Flux Dialysis? Still a Role Hoenich, N.A. (Newcastle upon Tyne)

193 High-Flux Hemodialysis and Hemodiafiltration. Impact on Outcome Locatelli, F.; Pozzoni, P.; Manzoni, C.; Di Filippo, S. (Lecco)

201 On-Line Hemodiafiltration. Gold Standard or Top Therapy? Passlick-Deetjen, J. Pohlmeier, R. (Bad Homburg)

212 New Options for On-Line Hemodiafiltration

Tetta, C. (Mirandola); Ghezzi, P.M. (Cuneo); De Nitti, C.; Fiorenzi, A.; Cianciavicchia, D.; Gervasio, R. (Mirandola)

221 On-Line Hemofiltration. Old Concept - New Approach Ledebo, I. (Lund)

227 The Ideal Hemodialysis Machine Polaschegg, H.-D. (Köstenberg)

Dialysis Machines, Monitoring and Biofeedback

233 Blood Volume Monitoring Systems and Biofeedback Santoro, A.; Mancini, E. (Bologna)

245 Blood Temperature Monitor: A Novel Tool in the Management of Dialysis-Induced Hypotension van der Sande, F.M.; Kooman, J.P.; Leunissen, K.M.L. (Maastricht)

254 Optimization of Convection on Hemodiafiltration by Transmembrane Pressure Monitoring and Biofeedback Pedrini, L.A.; De Cristofaro, V.; Pagliari, B.; Filippini, M.; Ruggiero, P. (Sondrio)

260 Potassium Profiling in Acetate-Free Biofiltration Santoro, A.; Mancini, E. (Bologna); Fontanazzi, F.; Paolini, F. (Medolla)

268 On-Line Clearance: Advanced Methodology to Monitor Adequacy of Dialysis at No Cost Gotch, F.A. (San Francisco, Calif.) 
272 Dry Weight Determination

Levin, N.W. (New York, N.Y.); Folden, T.; Zhu, F. (New York, N.Y.),

Ronco, C. (Vicenza)

Data Acquisition and Management

279 Information Technology Applied to Hemodialysis

Ronco, C. (Vicenza); Levin, N.W. (New York, N.Y.); Milan, M. (Vicenza)

287 Practical Approach to Data Collection in a European

Dialysis Network

Hegbrant, J. (Lund/Denver, Colo.); Alper, A. (Denver, Colo.);

Bosch, J.P. (Stockholm/Denver, Colo.)

293 Data Management and Quality Assurance for Dialysis Network

Marcelli, D.; Moscardó, V.; Steil, H.; Day, M.; Kirchgessner, J.; Mitteregger, A.;

Orlandini, G.; Gatti, E. (Bad Homburg)

300 Continuous Quality Improvement for a Hemodialysis Network

Bosch, J.P.; Walters, B.A.J. (Fort Lauderdale, Fla.)

311 Pre-End-Stage Renal Disease and Dialysis Programs:

The View of the Manager

Donald, L.L. (New York, N.Y.)

Dialysis Quality and Composition

317 Water Treatment for Hemodialysis

Cappelli, G.; Inguaggiato, P.; Ferramosca, E.; Albertazzi, A. (Modena)

325 Dialysate Purity: A Must

Ramírez, R.; Carracedo, J.; Martín-Malo, A.; Rodríguez, M.; Aljama, P. (Córdoba)

332 On-Line Fluid Preparation

Lonnemann, G. (Langenhagen)

338 Sodium Content and Profiling

Locatelli, F.; Colzani, S.; Pozzoni, P.; Manzoni, C.; Di Filippo, S. (Lecco)

344 Dialysate/Infusate Composition and Infusion Mode in On-Line Hemodiafiltration

Pedrini, L.A.; De Cristofaro, V.; Pagliari, B.; Ruggiero, P. (Bergamo)

350 Dialysate/Infusate Calcium and Magnesium

Vitale, C.; Marangella, M.; Ramello, A. (Turin)

357 Dialysate/Infusate Buffer Modulation in Dialysis

Feriani, M. (Mestre-Venezia)

Chronic Inflammation

364 Chronic Inflammation: An Overview

Levin, N.W. (New York, N.Y.); Ronco, C. (Vicenza) 
371 Oxidant Stress in Hemodialysis Patients

Galli, F.; Floridi, A.; Buoncristiani, U. (Perugia)

379 End-Stage Renal Disease: A Slowly Progressive Systemic Inflammatory Response Syndrome

Ronco, C. (Vicenza); Levin, N.W. (New York, N.Y.)

386 LDL Modification during Hemodialysis. Markers for Oxidative Stress Sevanian, A.; Asatryan, L. (Los Angeles, Calif.)

Anemia Management

396 Erythropoietin Therapy in Europe: Results from the DOPPS Pisoni, R. (Ann Arbor, Mich.)

403 Clinical Experience with Darbepoetin-Alfa (Aranesp ${ }^{\circledR}$ ) Locatelli, F.; Del Vecchio, L.; Marai, P. (Lecco)

408 Once-Weekly Epoetin-Beta in Renal Anemia: The Clinical Evidence Albertazzi, A. (Modena)

412 Iron Therapy in Hemodialysis Patients: How and When? Crepaldi, C.; Bordoni, V.; Carta, M.R. (Vicenza)

426 Carnitine as Adjuvant Therapy in the Management of Renal Anemia Cianciaruso, B.; Torraca, S.; De Blasio, A.; Fiorillo, M.; Marino, R. (Naples)

431 Erythropoietin Therapy and the Cardiovascular System Santoro, A. (Bologna)

436 Author Index

438 Subject Index 


\section{Preface}

Replacement of renal function by dialysis is a well-established form of treatment. The number of patients suffering from end-stage renal disease is continuously increasing and the combined challenge today is both to provide dialysis for all individuals who need it, and to provide a quality of therapy such as to improve medium and long-term outcomes. In this setting, hemodialysis technology can be of help for clinicians who prescribe the treatment and the nurses and technicians who deliver the prescribed therapy. Dialysis, however, is a rapidly changing field. The knowledge that physicians have in terms of machinery and disposables is estimated to last for a maximum of 5 years and if no refresher or educational courses are attended, large areas of ignorance can be expected. On the other hand, the knowledge of nurses and technicians who daily operate with new machines and the most recent devices has the risk of remaining superficial and mechanical if adequate information is not provided in terms of theory and the principles behind the practical procedures. For this reason, we feel that both for physicians and nurses this course can represent an invaluable occasion of education and information. The course is integrated in a program of continuous medical education generated by the Department of Nephrology of St. Bortolo Hospital in Vicenza, accredited with CME credits both by the Italian Ministry of Health and the UEMS (Union Européenne des Médecins Spécialistes). The course includes all the aspects related to the hemodialysis technology from the most basic to the most sophisticated.

An outstanding group of experts in the field discuss aspects related to vascular access and new forms of monitoring of access function. Anticoagulation strategies and antimicrobial treatment are debated with special emphasis on temporary catheters and prosthetic devices.

Membrane composition and structure, methods of sterilization and performance are discussed by a mixture of experts and manufacturers leading to a perfect integration of science, theory and manufacturing procedures. The same 
synthesis is achieved in the sessions related to hemodialyzers, adsorbent devices, dialysis techniques and machines. A new interest has also arisen in the possibility of computer-assisted data collection and managing. For this reason, experts in the field of electronic management of data together with managers of large dialysis networks are involved in the discussion of quality assurance and continuous quality improvement programs.

Special attention is given to dialysate and water purity since this is the starting point for newer dialytic techniques such as on-line hemodiafiltration. This is of paramount importance since chronic inflammation seems to represent one of the factors involved in long-term dialysis outcomes. In this view, the results obtained from the IDOPPS study are incorporated into the discussion of different practice patterns and anemia management could not be neglected. Finally, future trends are explored including automatic sensors and biofeedback monitors.

The format of the course is the one traditionally scheduled for the Vicenzanephrocourses. Every year a new event takes place but the topics (traditionally peritoneal dialysis, critical care nephrology and hemodialysis technology) are repeated only every 3 years. This year all the topics are presented by the most important and regarded experts in the field. In this course, the partnership between the academic world and industry is transparent and perfectly integrated. The final common target is the improvement of outcomes through the research and development of new technology. We are grateful to all the institutions, companies and individuals who made the event possible.

Claudio Ronco

Giuseppe La Greca 